\title{
ACRL wants you!
}

Reap the many benefits of volunteerism

$\mathbf{N}$ ow is a good time to increase your involvement in ACRL by volunteering to serve on a division or section committee. Vicepresident Maureen Sullivan invites all ACRL members to contact the Appointments Committee about serving on one of ACRL's 20 committees for next year. Members may also contact one of the section vice-chairs regarding service on one of the many section committees.

ACRL has recently adopted a new Strategic plan (available at http://www.ala.org/acrl/ stratpla.html), and during the next few years committee members will have an opportunity to help implement this plan, reshape the association, and influence the clirection of academic and research librarianship.

\section{You benefit by volunteering}

Volunteers not only give to the association, they get back from the association:

- Build ties with acadenic and research librarians around the country.

- Enhance your leadership abilities through consensus building and persuasion.

- Share your expertise with colleagues.

- Gain aclditional expertise-learn more about a new area of academic librarianship or pick up new ideas for your current area.

\section{Appointments: The process}

Appointments are made at both the section and division levels. The ACRL president is responsible for the committee appointments at the division level for the year he or she serves as president. Likewise, section chairs are responsible for committee appointments in their respective sections the year they serve as chair. Committee slates are usually completed shortly after the Midwinter Meeting during the year in which the indiviclual serves as president-elect or chair-elect. The ACRL Appoinuments Committee assists the president-elect in this process in an advisory capacity.

\section{Factors influencing appointment}

Although the emphasis in the appointment may vary from year to year according to the prerogatives of the president-elect and sec tion chairs, the same factors are considered. They include:

- Evidence of potential committee member's interest: Have you attended the meetings and introduced yourself to the chair? Do you have previous experience that relates to the work of the committee? Have you indicated your interest on the volunteer form?

- Demographics and composition of committee: A balance is sought with respect to type of library (community college, college, or university), geographic representation, ethnic diversity, and gencler.

- The recommendation of the current committee chair: Current committee chairs are asked to suggest potential members. $\mathrm{Al}$ though all of these factors are considered. the final appointments are the prerogative of the ACRL president-elect and the section chair-elects.

\section{How to apply}

1) Select the committees that interest you. The ALA Handbook of Organization lists all of ACRL's committees and their charges. ( $E d$. note: The Handbook will be published as at special issue of American Libiaries and will automatically be mailed to all ALA members in mid-November.) Attend the committee's meetings at the Midwinter Meeting and Annual Conference to help you decide if those are the activities that interest you.

2) Introduce yourself. Talk with committee members. Express your interest to the committee chair. Explain how you might contril)ute to the work of the committee.

3) Submit a volunteer form. Complete the volunteer form included with this article. ( $\mathrm{Ed}$. note: This form is also available on ACRL's homepage at http://www.ala.org/acrl/ comcall.html.) Be sure to cover all of the items asked for in background information. If you have attended committee meetings or programs, 
out one form for ACRL division committees and a different form for each ACRL section you volunteer to serve on a committee for. Send the ACRL committee volunteer form to Mary Jane Scherdin at the address on the bottom of the volunteer form: send the section volunteer forms to the appropriate section chair-elects (see list of addresses below).

4) Volunteer again ... and again. If you are not successful in being appointed one year, volunteer again the next year... and the next. Remember that a multitude of factors-number of appointments made, number of volunteers for each committee, number of volunteers from your type of library or your geographic area-determine the actual appointment, and these factors change from year to year.

\section{ACRL section appointments}

ACRL has 17 sections (listed below). You will find a description of their areas of responsibility in the ALA Handbook of Organization. 1997-98. Many of ACRL's sections have developed new homepages that are linked to ACRL's; check out http://www.ala.org/ acrl.html. The chair-elect of a section appoints the chair and members of all section committees. Most of these appointments are made in the spring for terms beginning immediately after the ALA Annual Conference. If you would like to be considered for appointment as a chair or member of a section committee, fill out the ACRL Committee Volunteer Form and mail it to the chair-elect of the appropriate section listed below before December 5, 1997.

African-American Studies Librarians Section. Vice-Chair/Chair-Elect: Sylvernal V. Ford, Iirector, Library Services and Information Technology, Mankato State University. Preferred address: 23 Partriclge Pl., North Mankato, MN 56003; e-mail: sylverna_ford@ms1.mankato.msus.edu.

\section{Anthropology and Sociology Section. Vice-} Chair/Chair-Elect: J. Christina Smith. Reference Librarian Bibliographer, Boston University. Preferred address: 135 Washington St., Malden, MA 02148-3720; e-mail: jchris@bu.edu.

Arts Section. Vice-Chair/Chair-Elect: Judy Harvey Sahak, Librarian, Assistant Director, Claremont Colleges, Denison Library. Preferred address: 2301 Tulsa Ave., Claremont, CA 917111666; e-mail: jharveysahak@rocky.claremont.edu.
Asian, African and Middle Eastern Section. Vice-Chair/Chair-Elect: David Hirsh, Middle East Bibliographer, University Research Library, University of California at Los Angeles. Preferred address: 1751 S. Barrington Ave., Apt. 3, Los Angeles, CA 90025-4064: e-mail: clluirsch@library.ucla.edu.

College Libraries Section. Vice-Chair/ChairElect: Carolyn A. Sheehy, Clare and Lucy Oesterle Director of Library Services, Oesterle Library, 320 E. School Ave., Naperville, IL 60540; e-mail: cas@noctrledu.

\section{Community and Junior College Libraries}

Section. Vice-Chair/Chair-Elect: Cary Sowell, Head Librarian, Northridge Learning Resource Center, Austin Community College. Preferred address: 1018 Hermitage Dr., Austin, TX 787535864; e-mail: cary@austin.cc.tx.us.

\section{Education and Behavioral Sciences Section.} Vice-Chair/Chair-Elect: Janice M. Wilson, Librarian, California School of Professional Psychology. Preferred address: 1180 E. Palm St., Altadena, CA 91001-1720; e-mail: jwilcspp@class.org

English and American Literature Section. Vice-Chatir/Chair-Elect: Roblent W. Melton, Publications Coordinator, University of Kansals. Preferred address: 2711 W. 24th Terrace, Lawrence, KS 66047 2822; e-mail: rmelton@ukanvm.cc.ukans.edu

\section{Extended Campus Library Services Section.} Vice-Chair/Chair-Elect: Robert P. Morrison, Reference Librarian, Coordinator of Distance Education Service, Merrill Library, Utah State University, Logan, UT 84322-3000; e-mail: robmor@cc.usu.edu.

Instruction Section. Vice-Chair/Chair-Elect: Mary Jane Petrowski, Case Library, Colgate University. Preferred address: 3347 Bishop Hill Rd., Madison, NY 13402-9724; e-mail: mpetrowski@center.colgate.edu.

Law and Political Science Section. ViceChair/Chair-Elect: Paula J. Popma, Orradre Library, Santa Clara University, Santa Clara, CA 95053; e-mail: ppopma@scuacc.scu.edu.

Rare Books and Manuscripts Section. ViceChair/Chair-Elect: Richard W. Oram, Librarian, Harry Ransom Humanities Research Center, University of Texas at Austin, P.O. Box 7219, Austin, 
TX 78713-7219; e-mail: roram@mail.utexas.edu.

Science and Technology Section. ViceChair/Chair-Elect: Billie Joy Reinhart, Cleveland State University Library. Preferred address: 1514 Burlington Rd., Cleveland Heights, $\mathrm{OH} 44118$; e-mail: b.reinhart(16)suchio.edu.

Slavic and East European Section. ViceChair/Chair-Elect: Tatiana Goerner Barr, Original and Special Materials Cataloger, Columbia University Lilbraries. Preferred address: 560 Riversicle Dr., Apt. 10M, New York, NY 10027 3241; e-mail: tb103@columbia.edu.

University Libraries Section. Vice-Chair Chair-Elect: Maureen Pastine, University Librarian, Paley Library, Temple University, 13 Berks Mall 017-00, Philadelphia, PA 17122; fax: (215) 204-5201.

Western European Specialists Section. ViceChair/Chair-Flect: Stephen Lehmann, Humanities Bibliographer, University of Pennsylvania Library. Preferred address: 300 Harvard Ave., Swarthmore, PA 19081; e-mail: lehmann@pobox.upenn.edu.

Women's Studies Section. Vice-Chair/ChairElect: Kristin H. Gerhard, Iowa State University, 204 Parks Library, Ames, IA 50011; e-mail kgerhard@iastate.edu.

\section{ACRL divisional committee appointments}

ACRL has 20 standing committees to which appointments may be made for 1998-99. A list appears on the volunteer form at the end of this article. You will find the committees listed with a description of their charges in the $A L A$ Handbook of Organization.

Appointments to ACRL standing committees are made in the spring for terms beginning immediately after the ALA Annual Conference. The Appointments Committee recommends to the presiclent-elect of ACRL the names of members who might fill the vacancies. The presidentelect makes the final appointments. If you are interested in being considered for an appointment to an ACRL committee, you should complete the Committee Volunteer Form and send it to Mary Jane Scherdin at the actdress given on the form before December 5, 1997.

\section{Editorial boards}

ACRL has editorial boards for these six publi- cations: Choice, College \& Research Libraries; College E Research Libraries Neus; New Publications; Publications in Librarianship, and Rare Books E Manuscripts Librarianship.

Appointments to editorial boards are made at the Midwinter Meeting for terms that begin immediately after the ALA Annual Conference. The editors recommend the name of a person to fill the vacancy. The Publications Committee must approve the recommendation, and the president of ACRL makes the appointment.

If you would like to be consiclered for appointment to an editorial board, contact the editor of the editorial board early in the fall.

Choice editor: Ir ing Rockwood, Choice, 100 Riverview Center, Middletown, CT 06457; e-mail: irockwood@ala-choice.org.

College \& Research Libraries editor: Donald E. Riggs, Nova Southeastern University, Fort Lauderdale, FL 33314-7796; e-mail: driggs@ nsu.acast.nova.edu.

College \& Research Libraries News editor: Mary Ellen Davis, CERL Neus, ACRL/ALA, 50 E. Huron St., Chicago, IL. 60611-2795; e-mail: medavis@ala.org.

New publications editor: Hugh Thompson. ACRL/ALA, 50 E. Huron St., Chicago, IL 60611-2795; e-mail: hthompson@ala.org.

Publications in Librarianship editor: John Bucld, 304 West Blvd. N, Columbia, MO 65203; e-mail: libsjmb@showme.missouri.edu.

Rare Books \& Manuscripts Librarianship editor: Siclney E. Berger, University of California, University Library, P.O. Box 5900, Riversicle, CA 92517-5900; e-mail: sidney. berger@ucr.edu.

\section{Feature your collection on the cover of C\&RL News}

CERL Neus wants to feature aesthetically pleasing photos of items from library collections on its covers. If you have material in your library's collections that you think would make an attractive CERL News cover, please send us a photograph or a color photocopy and a brief description of the item and the collection. Photos may be either color or black-and-white and should be 5 " $\mathrm{x}$ $7^{\prime \prime}$ or $8^{\prime \prime} \times 10^{\prime \prime}$. Illustrations with a vertical orientation work best. Send to: CERL News Covers, 50 E. Huron St., Chicago, IL 60611. 


\section{ACRL committee volunteer form}

\section{Background information}

On a separate single sheet of paper briefly summarize your background and activities in the following areas: 1) ALA professional activities; 2) ACRL professional activities; 3) state and regional offices held and committee appointments; 4) educational background and/ or other experience that will assist the committee in the appointment process; 5) publications.

Please include in your application an expression of your professional concerns and the contribution that you can make toward strengthening ACRL.

\section{| Date of Application:}

Name:

Job title:

I Daytime phone:

Fax number:

| E-mail address:

Organization/library:

1 | Institution's address:

।

|

।

| Ethnicity (optional):

|

\section{Division committees}

To volunteer for a division committee, complete this form and return it to:

Mary Jane Scherdin

Edgewood College

859 Woodrow Street

Madison, WI 53711

e-mail: scherdin@edgewood.edu
The following divisionwide committees have vacancies annually. Please indicate your first three choices by marking "1," "2," and " 3 " on the corresponding lines.

\section{Academic Librarians' Status}

(Hugh C.) Atkinson Memorial Award

Budget and Finance

Constitution and Bylaws

Copyright

Doctoral Dissertation Fellowship

Government Relations

Intellectual Freedom

International Relations

(Samuel ) Lazerow Fellowship for Research in

Acquisition or Technical Services

Media Resources

Membership

Professional Development

Professional Enhancement

Publications

Racial and Ethnic Diversity

Research

\section{(K. G.) Saur Award for Best College \&}

\section{Research Libraries article}

Standards and Accreditation

Statistics

I am willing to serve on any committee for which I am qualified and needed as a regular member or as an intern.

Note: By accepting an appointment, l agree that all working papers and final products of the group are the sole property of ACRL and are not to be used for any personal projects unless written permission has been obtained from the appropriate governing body. $I$ also certify that it does not represent a conflict of interest. I understand that failure to attend two meetings without an explanation acceptable to the chair constitutes grounds for removal.

Forms must be returned by December 5, 1997.

Membership in ALA and ACRL is required.

Attendance at Midwinter Meeting and Annual Conference is required. 


\section{Section committee volunteer form}

\section{Background information for section committees}

Provide a separate sheet of information about yourself following the instructions given on the ACRL committee volunteer form (previous page) under background information. To indicate your particular interest in serving on a committee in one of ACRL's 17 sections, write the committee name(s) next to the section below.

African-American Studies Librarians

Anthropology and Sociology

Arts

Asian, African and Middle Eastern

College Libraries

Community and Junior College Libraries

Education and Behavioral Sciences

English and American Literature

Extended Campus Library Services

Instruction

Law and Political Science

Rare Books and Manuscripts

Science and Technology

Slavic and East European

University Libraries

Western European Specialists

Women's Studies

Date of application:

Organization/library:

Name:

Job title :

Daytime phone:

Fax number:

E-rnail address:

Return form to:

Return this completed form to the appropriate section vice-chair/chair-elect as indicated in the accompanying article. (Use duplicate forms if you are interested in more than one section.) You must be a member of the section to be considered for appointment.

Forms must be returned by December 5, 1997.

Membership in ALA and ACRL is required.

Institution's address:

Ethnicity (optional)

Note: By accepting an appointment, I agree that all working papers and final products of the group are the sole property of ACRL and are not to be used for any personal projects unless written permission has been obtained from the appropriate governing body. I also certify that it does not represent a conflict of interest. I understand that failure to attend two meetings without an explanation acceptable to the chair constitutes grounds for removal.

Attendance at Midwinter Meeting and Annual Conference is required. 